\title{
ESCREVER HISTÓRIAS PARA CONVENCER OS OUTROS: MEMÓRIAS, DIÁRIOS E CARTAS DE IMIGRANTES
}

- JORGE LUIZ DA CUNHA

Universidade Federal de Santa Maria

RESUMO

Escrever histórias, narrar e narrar-se são estratégias humanas de significação da relação com a realidade vivida e imaginada. Em memórias, diários e cartas de imigrantes, com vasto conteúdo biográfico e autobiográfico, encontram-se inúmeras referências à construção humana de si mesmo como um outro (RICOUER, 1991), para convencer familiares, amigos e até desconhecidos, da terra natal, a fazerem o mesmo, ainda que a realidade imigrante, no país de destino, seja insatisfatória ou, não raro, desastrosa. Os exemplos de narrativas de imigrantes - memórias, diários e cartas-, que se estabeleceram no Brasil, nos séculos XIX e XX, foram interpretadas a partir de princípios hermenêuticos. Os efeitos desta postura metodológica opõem-se de forma evidente ao influxo cartesiano, na pesquisa, no ensino e na cultura, e ultrapassam a eventual deficiência interpretativa das narrativas, não raro, associadas somente a técnicas ou métodos, como a semiótica, a análise de conteúdo, a análise do discurso. Como resultado, percebe-se uma importante e complexa relação das narrativas biográficas e autobiográficas aos contextos da realidade do país de origem e do país escolhido, neste caso, o Brasil, identificando a inscrição da existência pessoal significada em uma narrativa do mundo que dá sua forma e seu sentido à história de cada testemunho migrante.

Palavras-chave: Biografias. Autobiografias. Memórias, diários e cartas. Imigrantes.

\section{ABSTRACT}

WRITING STORIES TO CONVINCE OTHERS: MEMORIES, DIARIES AND LETTERS BY GERMAN IMMIGRANTS IN BRAZIL

Writing stories, narrating and narrating oneself are human strategies to signify the meaning of lived and imagined reality. In memoirs, diaries and letters of immigrants, with vast biographical and autobiographical content, one can find numerous references to the human construction of oneself as the other (Ricoeur) as a way to convince 
relatives, friends and even strangers of the native land even if the immigrant reality in the country of destination is unsatisfactory or disastrous. Examples of immigrant narratives - memoirs, diaries, and letters - that settled in Brazil in the 19th and 20th centuries were interpreted following a hermeneutical approach. The effects of this methodological position are clearly opposed to the cartesian influence in research, teaching and culture, overcoming the interpretative deficiency of narratives, often associated only with techniques or methods such as semiotics, content analysis, discourse analysis. As a result, one can notice an important and complex relationship between biographical and autobiographical narratives with the contexts of reality in the country of origin and the immigration country, in this case Brazil, identifying the inscription of personal existence signified in a narrative of the world that gives its form and meaning to the history of the testifying migrant.

Keywords: Biographies. Autobiographies. Memories, diaries and letters. Immigrants.

\section{RESUMEN ESCRIBIR HISTORIAS PARA CONVENCER LOS OTROS: MEMORIAS, DIARIOS Y CARTAS DE INMIGRANTES}

Escribir historias, narrar y narrarse son estrategias humanas de significación de la relación con la realidad vivida e imaginada. En memorias, diarios y cartas de inmigrantes, con vasto contenido biográfico y autobiográfico, se encuentran innumerables referencias a la construcción humana de sí mismo como otro (Ricouer, 1991) para convencer a familiares, amigos e incluso desconocidos, de la tierra natal a hacer el mesmo, aunque la realidad inmigrante, en el país de destino, sea insatisfactoria o, no raramente, desastrosa. Los ejemplos de narrativas de inmigrantes - memorias, diarios y cartas -, que se establecieron en Brasil en los siglos 19 y 20, fueron interpretadas a partir de principios hermenéuticos. Los efectos de esta postura metodológica se oponen de forma evidente al influjo cartesiano, en la investigación, en la enseñanza y en la cultura y sobrepasan la eventual deficiencia interpretativa de las narrativas, no raras, asociadas solamente a técnicas o métodos, como la semiótica, el análisis de contenido, el análisis del discurso. Como resultado, se percibe importante y compleja relación de las narrativas biográficas y autobiográficas con los contextos de la realidad del país de origen y del país escogido, en este caso Brasil, identificando la inscripción de la existencia personal significada en una narrativa del mundo que da su forma y, su sentido la historia de cada uno.

Palabras clave: Biografias. Autobiografias. Memorias, diarios y cartas. Inmigrantes. 


\section{Considerações iniciais}

Reconheço-me como brasileiro e sou descendente de imigrantes. De famílias que chegaram durante o século XIX, na Província de São Pedro do Rio Grande do Sul, extremo sul do Brasil. Os de sobrenome Da Cunha vieram de Portugal, da Freguesia de São Salvador da Carregosa, Aveiro. Os Ludwig emigraram do Cantão Wallis ou Canton du Valais, do sul da Suiça. Os Stormowski são originários da Prússia Oriental, hoje território da Polônia, de uma aldeia então chamada de Schwarzwasser, atualmente Czarna Woda, pertencente ao distrito de Stargard (Stôrgard). Os Franzen habitavam a cidade de Pünderich an der Mosel, na margem do Rio Mosela, na Renânia-Palatinado (Rheinland-Pfalz), atual Alemanha. Eu nasci, cresci, vivo e existo marcado por esta memória histórica.

Atualmente, como professor e pesquisador em uma universidade pública federal, no interior do Rio Grande do Sul, na cidade de Santa Maria, ocupo-me com o ensino na área de formação de professores e pesquisas relacionadas, principalmente, a narrativas autobiográficas e migrações humanas.

Uma das razões que fundamentam a escoIha do tema deste texto relaciona-se com uma experiência na disciplina de Metodologia da Pesquisa em Ciências Humanas, oferecida para mestrandos e doutorandos do Programa de Pós-Graduação em História, do Programa de Pós-Graduação em Educação, e do Mestrado Profissional em Rede Nacional em Ensino de História, desde o primeiro semestre de 2012. $\mathrm{Na}$ verdade, uma introdução ao papel fundamental da narrativa na pesquisa e no ensino, tanto como fonte, quanto como metodologia.

Em uma aula presencial introdutória, no primeiro semestre de 2014, fiz o seguinte relato oral:

- No final de semana passado, estimulado pelas informações de uma amiga e colega antro- póloga reconhecida internacionalmente, decidi participar de uma das (provavelmente) últimas colheitas de sagu que ainda acontece em três lugares remotos do Rio Grande do Sul.

Por recomendação dela, que em uma de nossas conversas havia me alertado sobre o desaparecimento deste tipo de agricultura, decidi conhecer e participar desta experiência comunitária pouco conhecida. Saí cedo de casa no último sábado e fui de carro até a comunidade de Walachai, um dos povoados do municipio de Morro Reuter, aqui no Rio Grande do Sul.

Segundo a tradição local as primeiras sementes de sagu, cujo nome científico é Semen Sago Orientales - o que indica sua origem possivelmente asiática -, foram trazidas pelos imigrantes germânicos que chegaram à localidade em meados da primeira metade do século XIX. Provavelmente por seu fundador proveniente de Echternach, em Luxemburgo.

Os descendentes de imigrantes alemães de Walachai não são os únicos que ainda cultivam sagu. Segunda minha colega da universidade, há mais duas comunidades que o cultivam, uma no interior de Vacaria e outra em um dos distritos de Nova Prata, todos aqui do nosso Estado.

Quando cheguei, a cerimônia que antecede a colheita, que dura no máximo dois ou três dias, já havia começado. Estavam todos com roupas claras, homens, mulheres, jovens e até algumas crianças, com as cabeças cobertas com chapéus, bonés e várias mulheres usando lenços. Todos carregando cestos forrados com tecidos, dos quais pendiam luvas cirúrgicas.

Cheguei no meio do discurso de uma das lideranças locais, que lembrava com lágrimas nos olhos e voz embargada que era preciso resistir. E que, ainda que o sagu natural de Walachai não conseguisse concorrer com os preços do sagu de fécula de mandioca que monopoliza o mercado, tratava-se de uma tradição a ser mantida. Para que nunca nenhum dos habitantes do lugar esquecesse quem era, esquecendo a história de sua família e de sua comunidade.

Depois do discurso, ouvimos todos ainda algumas recomendações de um técnico agrícola, aposentado da Empresa de Assistência Técnica 
e Extensão Rural - EMATER, e partimos para a lavoura de sagu da comunidade para iniciarmos a colheita.

A única lavoura de sagu de Walachai fica em uma área de cerca de dois hectares de propriedade coletiva comunitária, nos fundos do prédio da nova igreja católica do lugar. Um terreno inclinado e com boa drenagem. A visão do lugar me remeteu à memória das imagens de um dos filmes de Akira Kurosawa, a luz do sol iluminava a encosta coberta de arbustos cujos frutos maduros mostravam os minúsculos grãos brancos do sagu natural.

Começamos a colheita. Os pequenos grãos de sagu foram sendo colhidos cuidadosamente $e$ sendo depositados em grandes balaios artesanais forrados de material plástico. Lamentavelmente a produção de sagu de Walachai não chega ao mercado e é consumido apenas pelos membros da comunidade.

Uma experiência que para mim será inesquecível. Um patrimônio de nossa cultura regional, ameaçado contundentemente de desaparecimento. Segunda minha colega antropóloga, nem o Ministério da Cultura tem demonstrado interesse em financiar projetos que divulguem essa agricultura comunitária pouco conhecida, o que com certeza contribui para que em poucos anos ela desapareça e com ela uma das expressões culturais de nosso Estado.

A narrativa acima foi atenciosamente ouvida, muito bem recebida e intensamente comentada pelos mestrandos e doutorandos presentes na aula. Algumas das perguntas mais marcantes foram as relacionadas ao desconhecimento do "sagu", também como semente de uma planta. O sagu que utilizamos no sul do Brasil, como ingrediente de uma sobremesa tradicional, é produzido industrialmente com fécula, amido extraído de mandioca, mas também do milho, da batata ou do arroz. Houve também perguntas relacionadas à necessidade de mais informações sobre como acessar "esta importante e desconhecida informação cultural", através de bibliografias ou experiências presenciais.
Importante salientar, aqui, que o relato acima reproduzido é uma ficção. Uma mentira, ainda que interessante ou logicamente construída.

Diante disso, algumas questões se apresentam: - por que os ouvintes acreditaram? Por que alguns inclusive duvidaram da minha sinceridade quando informei que se tratava de uma mentira, cujo relato tinha a função de levar a uma reflexão sobre a importância da construção convincente de um texto científico? Acreditaram na mentira e não acreditaram na minha sinceridade!

Trata-se de um claro exemplo da naturalização de que Leão e Wrublewski (1993, p. 7) chamam de "de-cisão":

[...] que vive da perplexidade em pensar a identidade como identidade e não como igualdade, isto é, que vive da dificuldade de se encontrar com a identidade no próprio seio das diferenças. Esta de-cisão, ao instituir as dicotomias de um comparativo ontológico, se pronuncia pelo ser contra o nada, pela essência contra a aparência, pelo bem contra o mal, pelo inteligível contra o sensivel, pelo permanente contra o mutável, pelo verdadeiro contra o falso, pelo racional contra o animal, pelo necessário contra o contingente, pelo uno contra o múltiplo, pela sincronia contra a diacronia.

Os mestrandos e doutorandos, pesquisadores em formação, não teriam acreditado na "narrativa ficcional e mentirosa", se não tivessem encontrado nela referências concretas e prováveis que ligaram o que ouviram com o que já conheciam, com a hierarquia de valores relacionada com a construção lógica do texto narrado, com o reconhecimento do "professor" etc. Portanto, não há mentira absoluta e não há verdade completa!

Esta experiência prática me levou a pensar, a refletir e pesquisar sobre o papel da narrativa (ficcional ou real) sobre o mundo - mito, memória e história -, sobre os outros - biografia -, e sobre si mesmo - autobiografia -, 
como uma estratégica histórica de formação do humano desde a sua origem. Assim, fundamenta igualmente este ensaio que busca interpretar o escrever histórias, narrar e narrarse, como estratégias humanas de significação da relação com a realidade vivida e imaginada em memórias, diários e cartas de imigrantes. Material com vasto conteúdo biográfico e autobiográfico, onde se encontram inúmeras referências à construção humana de si mesmo como um outro (RICOUER, 1991), para convencer familiares, amigos e até desconhecidos, da terra natal, a fazerem o mesmo, ainda que a realidade imigrante, no país de destino, seja insatisfatória ou, não raro, desastrosa.

Nas memórias, diários e cartas de imigrantes que se estabeleceram no Brasil, nos séculos XIX e XX, interpretadas a partir de princípios hermenêuticos, percebe-se a importante e complexa relação das narrativas autobiográficas com os contextos da realidade do país de origem e do país escolhido, neste caso, o Brasil. Como afirma Delory-Momberger (2012, p. 118):

As narrativas de si contemporâneas das 'grandes narrativas' são tributárias de uma perspectiva coletiva e histórica que excede consideravelmente o contexto restrito da existência que elas revelam, inscrevendo essa existência numa 'narrativa do mundo' que dá sua forma e seu sentido à história individual.

Historicamente, dos gregos ao tempo presente, cada ser humano define-se individual e coletivamente, objetiva e subjetivamente, através da acepção sintética entre a existência no mundo e o significar-se nele através da linguagem, da narrativa. 0 mundo reconhecido como espaço humano, não é dado aos homens pelas forças transcendentes, mas é construído e incessantemente reconstruído e identificado pelos costumes, hábitos, prescrições, leis, normas, proibições, tabus, valores e ações. Ou seja, uma prática e uma reflexão, como hábi- tos, que articulam modos de ser e viver orientados pelo conhecimento, pela razão, mas também pelo desejo e pela imaginação. Tudo isso sempre identificado e acessado pela linguagem, pelas narrativas, caracterizadas por seu conteúdo biográfico ou autobiográfico, estrategicamente definido objetivamente, como imanente (à experiência sensível, relativa, contingente, multíplice e variável), ou subjetivamente, como metafísico (absoluto, necessário, único, imutável). Contudo, penso que o narrar o outro - que inclui o mundo -, e narrar a si, deve ser considerado como acesso a uma práxis social, cultural, política, de desnaturalização e estranhamento e, consequentemente, de exercício de unidade entre ser e pensar, viver e narrar.

\section{Da antiguidade à modernidade - a narrativa biográfica e autobiográfica como prática social e existencial}

No que consideramos a base da chamada civilização greco-romana e judaico-cristã ocidental, a própria mitologia grega, associada à intencionalidade de formatação da sociedade humana, cultural e política, tem um caráter claramente biográfico.

As narrativas, inclusive as de caráter histórico, segundo Veyne (1984, p. 22-23), tinham um público heterogêneo que acessava os conteúdos com distintos interesses, ao contrário da intenção moderna dos historiadores e dos demais pesquisadores de todas as áreas, que pesquisam e publicam seus resultados para outros historiadores, ou colegas de suas áreas de conhecimento; "[...] por isso se impõe sobretudo questionar o próprio poder da ciência em sua impotência de pensar" (LEÃO; WRUBLEWSKI, 1993, p. 15) Sendo assim, é possivel reconhecer que a própria verdade não se exprime pela boca de quem narra ou escreve: 
[...] cabe ao leitor fazer uma ideia dessa verdade; eis uma das inúmeras particularidades pouco visiveis que revelam que, apesar das grandes semelhanças, o gênero histórico, entre os Antigos, é muito diferente do que é entre os Modernos. [...] Cada historiador faz sua escolha: escrever para todos, atentando para as diversas categorias de leitores, ou especializar-se, na informação tecnicamente segura, que fornecerá dados sempre utilizáveis aos políticos ou aos militares. [...] Além do mais, a heterogeneidade do público deixava ao historiador alguma margem: podia apresentar a verdade sob cores mais cruas ou mais brandas, à vontade, sem por isso, traí-la. (VEYNE, 1984, p. 23-24).

Encontramos um exemplo em Hesíodo (1995), na obra chamada Teogonia (séculos VIII ou VII a. C), em que ele descreve como surgiu a humanidade através de uma narrativa de caráter claramente pedagógico e biográfico, ainda que mítico.

Livremente interpretado, o poema de $\mathrm{He}$ síodo anuncia que no começo dos tempos o mundo era habitado pelos titãs (enormidades, cuja meta é a dominação e o despotismo) e a humanidade, neste contexto, não existia (BRANDÃO, 2002). O humano não existe, pois, diante de enormidades. O humano somente existe onde o conhecimento é possivel - experiência sensivel, refletida, significada, guardada na memória e partilhada com outros humanos, através de processos dialógicos.

Cronos - o tempo mensurável -, o mais jovem dos titãs, gerado por Urano - a imensidão do céu -, e Gaia - a imensidão da terra -, torna-se o detentor máximo do poder entre os seres divinos, líder de todos os titãs. Amaldiçoado pelo pai com a profecia de que teria um filho que o destruiria, devora todos os filhos gerados por sua união com Réia. Diante do nascimento do seu sexto filho, Réia, com a ajuda de Gaia, trata de salvá-lo. Zeus, como é chamado, é levado para a ilha de Creta, para ser protegido da fúria de seu pai. Réia envolve uma grande pedra com os panos do recém- nascido e entrega o embrulho a Cronos que, sem suspeitar, o devora (KERÉNYI, 2015).

Zeus, protegido pelas ninfas, cresce seguro em Creta. Molhando seus pés descalços de criança nas ervas e flores que cobrem os campos, ainda úmidos pelo orvalho do amanhecer. Enquanto cresce, corre pelas pradarias, vales e montanhas da ilha, habituando-se a ver o Sol que nasce e ilumina a terra, em cada manhã e que se põe em cada entardecer. Alimentado com leite e mel, à noite, é posto para dormir em um leito forrado de ervas finas e perfumadas (JULIEN, 2005; BRANDÃO, 2002).

Adulto, lhe revelam que é filho de Cronos e que seu pai havia devorado seus irmãos. Sob a orientação de Metis - a prudência -, Zeus estabelece as estratégias para resgatar seus irmãos do interior de Cronos. Depois disso, ao lado de seus irmãos e irmãs e dos ciclopes dá início a uma guerra contra os titãs, que dura uma eternidade inteira. Vencedor, aprisiona as enormidades no Tártaro - uma região mítica habitada por monstros e na qual nenhum ser humano pode penetrar, sem "deixar de ser o que é". Assim, Zeus passa a reinar absoluto e ordena o mundo segundo sua vontade (JULIEN, 2005). Depois disso, surge na Terra a humanidade.

Há alguns aspectos neste mito grego que remetem a valores, relacionados à compreensão do humano, presentes já na cultura grega - alicerce da civilização a que pertencemos -, e que não devem ser desprezados quando tratamos de educação e de cuidado:

- Diante de um mundo habitado por enormidades, o humano não é possível, pela ausência de condições para produzir conhecimento. Desde os gregos, o conhecimento é entendido como um resultado do uso humano da inteligência, intimamente associado à aplicação dos sentidos sobre a realidade. Ou seja, conhecimento humano é processo reflexivo que se fundamenta na experiência sensivel. 
- As titânicas enormidades somente podem ser derrotadas e afastadas do mundo, para dar condição à preservação e ao desenvolvimento da humanidade, através do uso de estratégias e virtudes humanas. No mito grego, Zeus aprendeu a condição humana vivendo como um humano, que cresce exercitando seus sentidos, e especialmente a imaginação. Aqui encontramos o caráter biográfico da narrativa acima exposta, que descreve o surgimento, o desenvolvimento, a importância e a missão histórica de Zeus; com um papel claramente pedagógico focado na construção da identidade do humano.

Projetando-se através da história, dos tempos homéricos (até século $X$ a. C), que caracterizam a reflexão mitológica acima, até a ascensão do cristianismo (entre os séculos IV e $\checkmark$ de nossa era) e sua dominação pelo clero, que o organiza hierarquicamente, reproduzindo a organização dos poderes que caracterizavam o Império Romano, chegamos a um período em que as narrativas orais se tornam hegemônicas, como estratégia de difusão e convencimento. A escrita restringe-se à elite e aos detentores do poder, principalmente como registro de sua legitimidade, alicerçada nos fundamentos do cristianismo. Contudo, há marcos fundamentais do papel do biográfico e do autobiográfico na interpretação deste tempo e de sua história, "pois as verdades da fé, para serem propagadas, devem assentar também sobre um sólido fundamento de cultura humana, a fim de que mais facilmente possam tornar-se convicções racionais" (RICCl, 1956, p. 7), e consequentemente aceitas pela maioria iletrada da população.

Em Agostinho de Hipona, Aurelius Augustinus Hipponensis (354-430), conhecido como Santo Agostinho, um dos clássicos do cristianismo e da filosofia medieval, através de sua obra Confissões (SANTO AGOSTINHO, 1984; 2017) encontramos o registro de um exemplo contundente. Essa obra de Agostinho tem um caráter catequético, mais estrategicamente acessivel e pedagógico do que $A$ cidade de Deus (SANTO AGOSTINHO, 2002) um clássico de cunho doutrinário. A prática narrativa de Santo Agostinho é historicamente inovadora. Na primeira parte (Livros I a X) de seu livro As Confissões - que se distingue da segunda parte (Livros XI a XIII), onde reflete sobre a Sagradas Escrituras -, apresenta-se autobiograficamente e inaugura uma nova forma de narrar-se por alicerçar sua escrita de si em sentimentos, motivações, lembranças de acontecimentos cotidianos de caráter individual; e, não como efeitos ou consequências de grandes acontecimentos descritos por historiadores e naturalizados por todos a partir de sua descrição convencionada.

O pensamento originário, ancorado na memória construída e associada à memória de outros ou à observação de caráter psicológico, nas Confissões de Agostinho ganha uma característica inovadora, ao instituir uma relação precisa entre o real descrito - autobiográfico -, mesmo que imaginado, e a crença no que somente pode ser reconhecido por ser sentido através da práxis da significação do descrito:

VIII, 13. Da infância, avançando rumo ao presente, não cheguei à puerícia? Ou melhor, ela não chegou a mim, e sucedeu à infância? Mas esta não foi embora: para onde iria? Contudo, já não era. De fato, eu já não era uma criança que não fala, mas um menino falante. Disso eu lembro; mas como aprendi a falar, só compreendi mais tarde. Com efeito, os adultos não me mostraram as palavras segundo um programa determinado de instrução, como um pouco mais tarde o alfabeto, mas eu mesmo com a mente que tu me deste, meu Deus, com gemidos e sons variados e gestos variados dos membros queria manifestar os sentimentos do meu coração, para que meus desejos fossem atendidos. Mas não conseguia expressar tudo o que queria para todos aqueles dos quais o queria. Apelava à memória: quando eles nomeavam algo e moviam o corpo 
em direção àquilo de acordo com aquele som, olhava e memorizava o som pelo qual chamavam a coisa que queriam indicar. [...] Dessa maneira, retinha as palavras colocadas no lugar adequado em várias sentenças ouvidas repetidamente, registrava de que coisas eram signos e, forçando a boca a reproduzir aqueles sinais, já conseguia comunicar meus desejos através deles. (SANTO AGOSTINHO, 2017, p. 43)

A obra Confissões de Agostinho (SANTO AGOSTINHO, 1984, 2017) tem um papel estratégico na expansão e na hegemonia do cristianismo na Europa Central, durante os séculos II e XII, por tornarem possível o "conhecimento de Deus" através da vivência, da memória e do relato sobre a própria experiência do sujeito, que, através dela, pode se reconhecer como "parte d'Ele". Ainda que não seja objetivo deste artigo avançar nesta reflexão, é importante ressaltar que o sujeito, uma "alma solitária" - até então reconhecido como cristão por sua adesão prática às escritas do "novo testamento", e por sua esperança de salvação pela superação dos males deste mundo através da morte -, passa a descobrir e participar da unidade do universo do criador, a partir do reconhecimento de si, no exercício autobiográfico de significar sua existência pelo que conta dela; e, neste exercício, supera a construção social do indivíduo ancorada na determinação externa da pregação doutrinária e alcança aí um caráter manifestamente filosófico.

Um novo e importante passo no papel da biografia e autobiografia na constituição do humano acontece no século $\mathrm{XI}$, e tem como exemplo original uma mulher, Hildegard von Bingen (1098-1179), entre outros pensadores da época, como Anselmo da Cantuária (FISCHER, 1911; HOLLISTER, 1982) e Pedro Abelardo (ABELARDO, 1984; BONI, 2003). Estes autores fundamentam os princípios do que chamamos de escolástica ou escolasticismo, que traz para o mundo prático, especialmente para os espaços escolares, o princípio dialético do exercício dinâmico entre o acreditar, para buscar entender, e o entender para que se possa acreditar. Esta postura teve um efeito sobre o conceito de humano através da consciência de si e do papel das relações humanas nesta produção, a partir da ruptura da rigidez das regras impostas por uma sociedade e cultura definidas por doutrinas e determinações hierárquicas externas. Em assim sendo, apresenta-se como um primeiro passo em direção a uma postura existencial, ancorada no primado da intenção e do consentimento, que se anunciam como base da construção moderna da convivência democrática e do reconhecimento da igualdade social, até hoje ainda em construção.

Nascida em Bermersheim vor der Höhe, no vale do Rio Reno - Renânia Palatinado -, Hildegard von Bingen apresenta-se como um exemplo associado às grandes transformações que caracterizam este período. Uma época marcada pela hegemonia cristã na Europa, representada pela Igreja Católica Apostólica Romana, através da renovação estratégicateórica-filosófica associada à Reforma Gregoriana, instituída por Leão IX, entre os anos de 1049 e 1054; e por sua tentativa de expansão através das Cruzadas, entre os séculos XI e XIII. Hildegard, filha de uma família da baixa nobreza, tornou-se uma monja beneditina caracterizada por seu misticismo, por suas teorias teológicas, mas também por suas composições musicais, seus escritos naturalistas (nutricionistas e fitoterápicos), ensaios sobre juventude, puberdade e sexualidade - especialmente a feminina - além de peças poéticas, dramatúrgicas e literárias (NEWMAN, 1999; SCHIPPERGES, 1997).

Em suas principais obras, especialmente Liver Scivias Domini - livro sobre os caminhos do Senhor -, escrito entre 1141 e 1151 (BINGEN, 1990; 1992); Liber Vitae Meritorum - livro sobre os méritos da vida -, escrito entre 1158 e 1163 (BINGEN, 1997); e Liber Divinorum Operum Sim- 
plicis Hominis - livro sobre as obras divinas para o homem comum -, escrito entre 1163 de 1173 (BINGEN, 1998; 2009), Hildegard von Bingen adota um caráter visionário, o que possivelmente a protegeu de acusações de heresia e abriu as portas para o seu reconhecimento. Em minha opinião, é de grande importância recuperar alguns de seus principais conceitos, limitados a alguns exemplos, para estimular a reflexão sobre o papel da narrativa autobiográfica na superação do conceito semântico de identidade e para a reconquista da unidade humana na diversidade existencial dos tempos presentes.

Fundamental é a dedução de que a postu$\mathrm{ra}$, as reflexões (ainda que fundamentalmente místicas) e os escritos de Hildegard von Bingen induzem a um grande avanço no conceito de humano; que pode ser associado ao papel de outros autores de sua época, na construção da modernidade. Um deles, que chama a atenção, é o de que existir por si e existir por outros são duas maneiras distintas de existir (GILSON, 2007, p. 291-301; 307-311). Até o começo do segundo milênio, o conceito fundamental do humano estava associado à ideia de que o homem era produto da vontade do criador. A partir daí, projeta-se e se desenvolve a ideia de que Deus é a matéria de que o universo é feito, e reconhecer-se nele - a partir da reflexão e do conhecimento sobre nossa existência - são invenções de si que podem levar a experiências da consciência de si. $E$, no campo religioso, ao reconhecimento de que tudo no universo, e toda a inspiração provocada por seu conhecimento, é uma possibilidade de conhecer a Deus. É inevitável concluir que esta postura dialética contribuiu muito para os conceitos modernos e presentes do eu e do outro, e do aqui e do mundo/universo, práticas filosóficas que não dispensam a práxis do biográfico e do autobiográfico, caracteristicamente contextualizada:
Erkennt der Mensch aber die Freude, die inm von einem anderen entgegenkommt, dann empfindet er in seinem Herzen ein grosses Entzücken. Denn dann erinnert sich die Seele, wie sie von Gott geschafen ist. (BINGEN, 1990, p. 91)'

Hildegard von Bingen anuncia que a compreensão do que é contrário e diferente não deve ser dispensada, pois todas as formas e presentações, apresentações e representações objetivas e materiais, acessadas pela experiência sensível, dão acesso ao substancial conhecimento da razão eterna. Desta forma, cada ser humano - reconhecido em sua diversidade e acessado pela narrativa de sua memória (autobiográfica) - é conhecimento da existência e da intenção do intelecto divino e universal de que todos fazem parte.

Esta base teológica e filosófica, que transita entre Agostinho e Hildegard von Bingen e caracteriza o tempo histórico ocidental europeu, que denominamos Idade Média, abre as portas para a modernidade e encontra uma ressonância significativa em Jean-Jacques Rousseau (1712-1778) e Walter Benjamin (18921940), ambos convocados aqui (também!) como exemplos.

Rousseau, em suas obras, especialmente as de caráter autobiográfico como as Cartas ao Senhor Malesherbes, de 1762 (MARQUES, 2005; LEIGH, 1972); Profissão de Fé do Vigário Saboiano, de 1762 (ROUSSEAU, 2004, p. 372-452; CASTRO, 2010); as Confissões, de 1770 (ROUSSEAU, 1965; 2008a); Diálogos de Rousseau Juiz de JeanJacques, de 1772 (SOËTARD, 2010) e Devaneios de um Caminhante Solitário, de 1776-78 (ROUSSEAU, 2008b); apresenta-se como um "filho do iluminismo, porquanto ele também fez guerra à história, à tradição, à sociedade" (PADOVANI; CASTAGNOLA, 1962, p. 288), e igualmente como um estratégico anti-iluminista, quando "admite

1 "Mas quando o ser humano percebe a alegria que vem de outro, ele sente um grande encantamento em seu coração. Porque então a alma lembra como foi criada por Deus". (BINGEN, 1990, p. 91) 
o primado do sentimento, da espontaneidade natural, que reconhece como fonte de todos os valores contra a razão, a cultura, a civilização, de que o iluminismo se vangloriava, e a que atribui ele a origem de todos os males" (PADOVANI; CASTAGNOLA, 1962, p. 288-289). Não há dúvidas de que esta postura intelectual e existencial de Rousseau também o faz ser reconhecido como um introdutor do romantismo.

Os escritos autobiográficos de Rousseau correspondem, em sua maioria, ao período final de sua vida, o último decênio anterior a 1778. Afirma em seus escritos que a memória de si, a recordação autobiográfica torna possivel recuperar a consciência da condição humana. $E$, portanto, oferece as condições para reagir diante da imposição de um mundo construído, estrutural e totalitário, pelas sociedades ocidentais. A verdadeira natureza humana é subtraída na modernidade pela artificialidade da imposição de um modelo de homem político determinado e previsivel, forçado a esquecer quem é de verdade. A recuperação da memória própria, portanto, impõe à educação o papel de dar sentido ao presente, de significar a memória resgatada e potencializar cada ser envolvido - agora consciente de sua natureza -, para a construção de um novo mundo. Sendo assim, o único sentido possivel para a educação, é nos devolver a posse dos princípios essenciais de nossa existência, em nós mesmos e em nossa relação com os outros:

Custa-me não só explicar as ideias, como até recebê-las. Estudei os homens e creio-me um observador razoável: contudo, nada sei ver do que vejo; só vejo bem aquilo de que me lembro, e só nas minhas recordações tenho espírito. Não sinto nada, não penetro em nada de quanto se diz, de quanto se faz, de quanto se passa na minha presença. 0 sinal exterior é tudo que me impressiona. Em seguida, porém, tudo isso me vem à memória: recordo-me do lugar, do tempo, do tom, do olhar, do gesto, da circunstância; nada me escapa. Acho então, pelo que se fez ou se disse, o que se pensou, e raramente me engano. (ROUSSEAU, 1965, p. 121)

Neste exercício memorial e autobiográfico, o espírito humano abandona a condição de resultado imposto por intenções e interesses exteriores, sempre legitimados pela naturalização da existência humana como animal, e, somente humana, se submetida a hierarquia do Estado:

Com isso, a autobiografia deixa de ser um 'romance engenhoso' ou um divertimento diletante e adquire um sentido novo. Não é mais a mim que eu peço que admirem ou lastimem, nem mesmo é pela 'humana condição' que testemunho, mas pela universalidade na qual cada um pode reconhecer cada um e reconhecer-se nele: 'Ser eterno, reúne em torno de mim a inumerável multidão de meus semelhantes [...]. Que cada um deles descubra por sua vez seu coração com a mesma sinceridade [...]'. (LEBRUN, 2006, p. 37, grifos do autor)

A partir de agora, proponho um salto, do século XVIII ao século XX, ainda que, neste interregno, vários autores especialmente da área das ciências sociais e humanas possam ser lembrados pelo uso e pela interpretação de narrativas biográficas e autobiográficas. Neste período, também teríamos exemplos importantes, no campo literário, como Johann Wolfgang von Goethe (1749-1832), com sua obra Fausto (GOETHE, 2007a; 2007b), especialmente por seu papel na construção e difusão do romantismo moderno e por sua crítica poética à modernidade capitalista, ancorada na aparência e na acumulação. Sem dúvida, em Goethe, poderíamos aprofundar vários aspectos relacionados aos usos representativos e simbólicos das narrativas, biográfica e autobiográfica, mas isto exigiria um espaço distinto deste. Sendo assim, nesta "genealogia" sobre os usos e sentidos da biografia e da autobiografia, convido a um deslocamento até Walter Benjamin (1892-1940). 
Trata-se de um autor das ciências sociais e humanas que combina correntes teóricas, aparentemente antagônicas, como o idealismo germânico, o materialismo dialético e o misticismo judaico, que, em suas obras, transparecem como pilares e contribuições relevantes para a construção de uma teoria estética que atribui à arte, especialmente à literatura, um papel social de provocação de sujeitos e coletivos e, consequentemente, de potencial criação de novas consciências. Benjamin conflui e contribui de forma original para a interpretação das memórias registradas em diários e cartas de imigrantes.

Opondo-se ao reconhecimento positivista de que diários somente podem ser considerados como acesso a realidade - portanto, prova documental -, se forem conectados ao calendário e à verdade descritiva de fatos vividos presencialmente pelo autor, Benjamin defende a posição de que, mais do que instrumentos de convencimento estético, os diários, mesmo de conteúdo romântico (característica da produção escrita do século XIX), são avivados pela fusão entre o autor - constituído de subjetividade, intencionalidade e ambição de reconhecimento -, o texto e a temporalidade. Apresentam-se, portanto, também como fundamentos éticos, valores e princípios da conduta humana (BENJAMIN, 1989; 1993a; 1993b). Como se vê, este conceito de Benjamin sobre os diários - no nosso caso, os diários de imigrantes ou sobre imigrantes fixados no Brasil durante os séculos XIX e XX -, não podem ser considerados meros documentos descritivos e, muito menos, ficcionais. Diários são parte do evento, do fato, da paisagem, que narram e também contêm o seu autor, que, mesmo sendo eletivo na afirmação ou na negação do que vê, vive e interpreta, o faz motivado e legitimado pela eleição ou seleção retórica. E mais: - não é o passado descrito e narrado que nos interessa, enquanto pesquisadores do campo biográfico e autobiográfico, é o papel destes registros, mesmo que de fragmentos memoriais do passado, na interpretação do presente e na significação de cada um e de todos nós neles, pois nos lemos nos diários escritos por outros.

Quanto às cartas de imigrantes, podemos nos apropriar delas, como fontes para a compreensão da complexidade do fenômeno migratório humano, a partir da interpretação e significação proposta por Benjamin, especialmente em suas próprias cartas, publicadas por Adorno e Scholem, depois de sua morte, em 1940; e mais recentemente (em 1997), na coleção completa das cartas de Benjamin, tornadas públicas através do trabalho de Gödde e Lonitz (BENJAMIN, 1978; 1997a; 1997b; 1997c; 1997d; 1997e; 1997f). Há alguns aspectos que chamam a atenção e inspiram o uso das narrativas em cartas de imigrantes para pesquisadores sobre o complexo tema da imigração:

- Em uma carta (BENJAMIN, 1997c, p. 233235) destinada a Siegfried Kracauer (18891966), um ensaísta alemão que costumava publicar em jornais, como o Frankfurter Zeitung, Benjamin afirma que está planejando escrever um ensaio sobre Moscou, inspirado por Kracauer, que havia escrito e publicado um ensaio sobre Paris. Contudo, reconhece que vai fragmentá-lo em notas e observações curtas, e não raro desconexas, deixando ao leitor por si próprio e com seus próprios recursos -, a tarefa de interpretar e significar o escrito. Informa, na carta, que está inspirado a escrever sobre Moscou, não com base na interpretação teórica, previsível e estruturada, mas na experiência sensivel do visto e do sentido: "Glanz über den Affairen - o brilho que envolve as coisas" (BENJAMIN, 1997c, p. 234; SELIGMANSILVA, 2009, p. 161-185). Uma exemplar ampliação desta posição de Benjamin acontece na obra Das Passagen-Werk, iniciada em 1927 e desenvolvida até sua morte, em 1940 (BENJA- 
MIN, 1993a; 1993b), onde reforça a tese de que o factual descrito não é uma idealização teórico-conceitual, mas uma teoria em si própria que instiga o leitor a criá-la. Assim, o colono, imigrante, que escreve cartas para familiares e amigos do país de origem, sempre o faz no campo da intencionalidade do biográfico e do autobiográfico. E não descreve uma realidade como ela de fato foi, mas, sim, uma vida lembrada por quem a viveu. Ainda assim é preciso reafirmar que, para o autor que rememora, não é o que ele de fato viveu, mas o télos - o propósito de plenitude da estruturação e a consumação da atitude (HEIDEGGER, 2002a; 2002b) - de sua rememoração, como hábito e práxis de presentificação da realidade vista, vivida, lembrada, narrada e significada, que dá sentido ao escrito e ao leitor que lê, criando com ele uma simbiose que pode alicerçar as condições de transposição dinâmica da identidade de quem escreveu para a unidade entre quem escreveu e quem leu.

\section{A versão e o fato nas memórias, diários e cartas de imigrantes}

Entre 1822 e o início da década de 1950, segundo as estatísticas brasileiras, cerca de cinco milhões de estrangeiros entraram como imigrantes no Brasil. 0 número de imigrantes alemães que se dirigiram, no período, para o Brasil é aparentemente pequeno - cerca de 255 mil, 5\% do número total. Contudo, a importância de sua participação na formação e no desenvolvimento, especialmente do sul do país, não pode ser ignorada. Os dados do censo brasileiro de 1940 fornecem uma indicação da expressividade de sua participação e de seus descendentes, na sociedade brasileira: cerca de 650 mil brasileiros natos falavam habitualmente o alemão e cerca de $460 \mathrm{mil}$ empregavam o italiano como principal língua de comunicação. A maior concentração deste contingente populacional encontrava-se, segundo o mesmo censo, no Rio Grande do Sul e em Santa Catarina, onde, respectivamente, 400 mil e 180 mil brasileiros falavam alemão. Os números referentes aos de língua italiana também são importantes na comparação, 300 mil no Rio Grande do Sul e 96 mil em Santa Catarina (CUNHA, 1995; 2004).

Deixar a terra natal, abandonar o costumeiro e buscar a sobrevivência em um lugar desconhecido - com todos os riscos e implicações de uma decisão deste tipo - exige fortes razões. São principalmente os pobres que migram, e o fazem quando sua vida tradicional se torna difícil ou impossivel. Juntam, então, seus últimos recursos, vendem seus trastes e partem em busca de um lugar onde supõem poder encontrar melhores condições de vida.

A realidade na Alemanha na segunda metade do século XIX produziu a emigração em massa. As condições de vida lá existentes tiveram íntima relação com os acontecimentos políticos da Europa no período. Após a derrota de Napoleão Bonaparte, os Estados alemães deram origem à Confederação Alemã, com sede em Frankfurt. Foi uma decisão do Congresso de Viena, realizado em 1815 pelos países vitoriosos, para reorganizar a Europa pós-napoleônica. A criação da Confederação constituiu-se no primeiro passo na direção da unificação, processo que se completaria no começo da década de 1870, quando surgiu o Segundo Império Alemão. Esse período de transição foi marcado por profundas transformações determinadas pela expansão das estruturas capitalistas sobre um quadro de declínio do feudalismo. 0 avanço do capitalismo do século XIX traduziu-se em industrialização, que, por sua vez, acelerou a constituição de um mercado nacional e a consequente unificação política. Cada passo em direção desta última foi marcado pelo avanço das cifras da produção industrial. Outro indicador do de- 
senvolvimento industrial alemão, durante o século XIX, foi a urbanização intensa. Graças à industrialização, inclusive agrícola, o campo era esvaziado de sua população. Em 1820, 80\% da população alemã ativa dedicava-se às atividades agrícolas; no ano de 1850, eram apenas $65 \%$; e, em 1870 , esse percentual caiu para $49 \%$ da população ativa, continuando em declínio até atingir, em 1910, somente $18 \%$. A unidade econômica que possibilitou a industrialização e o comércio exterior, que se desenvolveu rapidamente, associados ao espantoso crescimento da população, tornaram possivel a estruturação de um modelo econômico e social autoritário, sustentado pela acumulação e a concentração de capital nas mãos de uma pequena minoria e a sujeição dos trabalhadores do campo e das cidades a condições de vida miseráveis (CUNHA, 1996).

A política de estabelecimento de colônias agrícolas no Brasil iniciou-se em 1808. A preocupação do governo, nesse período, pautavase pela necessidade de aumentar a produção de gêneros alimentícios e de proteger as fronteiras despovoadas do Sul ante a ameaça do avanço espanhol, trazendo açorianos que se transformassem em soldados estancieiros. Em 1818, foi aprovada a criação de uma colônia de suiços de língua alemã, de cem famílias, no Rio de Janeiro, Nova Friburgo, estabelecida em 1819. Nova Friburgo inaugurou uma tradição de ajuda oficial para o estabelecimento de estrangeiros no Brasil. Os colonos de Cantão de Friburgo, todos católicos, conforme determinava o decreto, receberiam passagem paga da Suiça ao Rio de Janeiro e daí para a colônia, lotes de terra em plena propriedade, por concessão gratuita, além de animais e sementes. Os colonos suiços receberiam, ainda, o pagamento de diárias, nos dois primeiros anos de assentamento. Todos seriam, desde a sua chegada, naturalizados portugueses, gozando de todos os direitos dos demais súditos do reino.
Nova Friburgo não correspondeu às expectativas. As intenções e o capital empregado não alcançaram resultados e a maioria absoluta dos imigrantes suiços abandonou a região de Nova Friburgo, dirigindo-se para o Rio de Janeiro, onde muitos se instalaram como trabalhadores, artesãos e pequenos comerciantes, ou foram engajados na organização do primeiro batalhão militar de estrangeiros em 1823 (CUNHA, 1991; 2004).

No Rio Grande do Sul, São Leopoldo, Três Forquilhas e São Pedro de Alcântara das Torres foram as três colônias fundadas pelo governo geral, sob as mesmas bases do estabelecimento de colonos em Nova Friburgo, concessão gratuita de terras, ferramentas e subsídios. 0 estabelecimento de colônias de estrangeiros, pequenos proprietários que utilizavam sua própria força de trabalho, nas regiões não ligadas diretamente à produção para o mercado externo, atenuou os efeitos da crise de mão de obra na produção de alimentos e permitiu a migração de escravizados destas regiões para as regiões monocultoras, especialmente para o sudeste brasileiro (CUNHA, 2004). Este fato permitiu às elites econômicas e políticas brasileiras o adiamento da abolição da escravidão até o final do século XIX.

Há um ponto que não deve ser desprezado, na análise do contexto que motivou o começo da colonização alemã no Brasil, a necessidade política da formação de esquadrões de soldados que defendessem a independência brasileira ante as pretensões portuguesas. Pouco antes da independência, em 1ㅇ de setembro de 1822, embarcou para a Europa, onde chegou 95 dias depois, o major Georg Anton von Schäffer (1779-1836), nomeado Agent d'Affaires Politiques, por Dom Pedro. Suas instruções eram as de obter a adesão dos governos da Santa Aliança para a causa da independência do Brasil e angariar mercenários para a guerra iminente contra Portugal: 
Schäffer, segundo as instruções que recebera, deveria buscar uma disposição favorável à independência do Brasil junto das cortes de Viena e de outros reinos alemães, e logo em seguida tratar do planejamento e da organização da contratação de emigrantes que receberiam terras como colonos mas que deveriam, em tempo de guerra, ser rapidamente engajados como soldados para defender as fronteiras, especialmente do sul do país. A segunda parte de sua missão Schäffer desenvolveu em Hamburgo (1824-1826) e Bremen (1826-1828), de onde foram embarcados para o Brasil, em 21 expedições, cerca de 4,5 mil imigrantes, entre soldados e colonos. Os colonos e muitos dos soldados foram destinados a colônias de caráter agro-militar estrategicamente localizadas nas regiões isoladas de Santa Catarina e Rio Grande do Sul. O modo como se processou, na Europa, o recrutamento de colonos e soldados e a sorte dos batalhões de estrangeiros resultaram em completo descrédito da emigração para o Brasil entre os opositores de Dom Pedro I e entre a maioria dos governos europeus, especialmente na Alemanha. (CUNHA, 2004, p. 2)

De 1831 a 1834, praticamente anulou-se a imigração estrangeira para o Brasil, até que, neste último ano, um Ato Adicional, promulgado pela Regência, transferiu a competência da colonização com imigrantes para as províncias do Império. Contudo, de um modo geral, durante toda a Regência (1931-1840), os resultados da imigração estrangeira foram pífios. Houve um abandono oficial do assunto, em função dos graves distúrbios políticos que marcaram todo o período e ameaçaram a própria integridade do Império (CUNHA, 1996; 2004).

$\mathrm{Na}$ Alemanha, enquanto isso, desenvolvera-se uma nova posição sobre e emigração. Enquanto que nos anos de 1820 a questão migratória ainda era vista como uma questão sociopolítica interna de cada Estado, a partir dos anos de 1840, a emigração passou a ser encarada como pertinente e de grande significado para a nação alemã. 0 nacionalismo crescente dos anos de 1840, que apontava para a unifi- cação da Alemanha em um Estado nacional, englobou também a questão da emigração. Não se queria mais que os alemães emigrados ficassem alheios aos interesses nacionais. Em outras palavras, a emigração deveria passar a servir aos interesses alemães. A organização e a coordenação da emigração passaram a ser encaradas como fatores cruciais do desenvolvimento de uma política econômica na Alemanha. Os emigrados alemães deveriam garantir no estrangeiro a formação de um mercado consumidor para os produtos da nascente indústria da Alemanha, suprindo para a economia alemã a falta de colônias. Além disso, por intermédio de estreitas ligações econômicas, deveriam ser fortalecidas, também, as ligações culturais, garantindo entre os alemães emigrados a preservação da língua e dos costumes. Depois da guerra franco-prussiana de 18701871, que encerrou o processo de unificação alemã, a Alemanha estava em condições, através das indenizações de guerra e da concentração de poder proporcionada pela fundação do Reich, de dar continuidade ao seu acelerado processo de desenvolvimento industrial e em poucos anos tornar-se um concorrente respeitável dos outros países industrializados da Europa em disputa pelo mercado mundial (CUNHA, 1995).

A partir de 1896, oficial e cautelosamente, desenvolveu-se uma política germanista Deutschtumspolitik - em relação aos alemães já emigrados e aos que continuavam a emigrar ano após ano. Essa política assumiu um caráter sistemático, organizando-se a partir de uma legislação que procurava direcionar a emigração para regiões de interesse do Reich; do apoio à criação e à manutenção de escolas alemães no exterior; do apoio à organização da igreja evangélica alemã; da articulação das representações diplomáticas da Alemanha; e do fomento às organizações e associações que, na Alemanha, se dedicavam aos alemães 
e seus descendentes que viviam no estrangeiro. Essa Deutschtumspolitik fixou-se especialmente nos alemães e seus descendentes que viviam no sul do Brasil, buscando a manutenção de sua consciência nacional, através da preservação da cultura alemã (língua, música, canto e crença evangélica), mantendo os colonos imigrantes ligados à velha pátria e finalmente aproveitando este amor patriótico para criar um mercado para o consumo de produtos da indústria alemã (GOETSCH, 1898; BRUNN, 1971; CUNHA, 1995). No final do século XIX e no início do século $X X$, pode-se dizer que os esforços dos círculos coloniais e pangermanistas haviam sido recompensados no plano legislativo e no que diz respeito à disposição do governo alemão. Os planos e intenções, contudo, não corresponderam à realidade. A maciça propaganda através de inúmeros guias de emigração, relatórios de viagens e descrições das colônias alemãs no sul do Brasil - que propagavam abertamente a conquista econômica pacífica desta parte do globo para o Reich, com a ajuda dos colonos alemães - não conseguiu alcançar o grande público, nem fornecer um quadro preciso da realidade brasileira ou guindar o interesse geral da opinião pública na Alemanha sobre o Brasil a um nivel além do periférico. Muito menos, estimular o crescimento do número de emigrantes. A política emigratória do Reich perdeu assim seu fundamento, o emigrante.

Nesse contexto político e econômico, a produção e a publicação de relatos memoriais, diários de viagens, muitos deles de caráter intelectual ou científico (especialmente geográfico, econômico e político), e, principalmente, diários e cartas de imigrantes foram estrategicamente utilizados como forma de propagar interesses e estimular os deslocamentos migratórios.

No que diz respeito ao primeiro grupo, relatos memoriais e diários de viagens, é impor- tante salientar que muitas das obras e suas publicações foram financiadas pelo governo brasileiro, especialmente na segunda metade do século XIX; ou até pelo governo alemão, depois da unificação do Reich em 1871 e da aplicação de sua primeira legislação sobre emigração, datada de 9 de junho de 1897 (GOETSCH, 1898; CUNHA, 1995).

São exemplares as publicações associadas aos diários de viagens ao sul do Brasil. Entre muitos, alguns exemplos, como o médico Avé -Lallemant (1859), que descreve sua viagem pelo Rio Grande do Sul, realizada em 1858, expressando seu encantamento através da descrição idílica de diferentes paisagens: "Enquanto assim, no céu, apareciam as estrelas, tudo na terra parecia dormitar, ...o rio forceja para destruir a mata e a mata para estorvar o rio. Mas, na luta caótica geram-se sempre novas formas, grupos e quadros da natureza" (AVÉ-LALLEMANT, 1859, p. 162-163), e cenários que envolviam imigrantes colonos alemães:

Nenhuma torre brilha a distância, nenhuma aldeia, nenhuma casa. Apenas um lugar, cuja coloração poderia lembrar a cultura do solo. Só a fumaça, que sobe lentamente de alguns pontos, anuncia que audazes agricultores já se estabeleceram no vale solitário, que do caos da natureza selvagem brotará uma cultura. [...] no meio de um campo, entre cinzas e carvões, encontrei um belo rapaz - um Mário entre as ruínas de Cartago; há um ano fazia queimadas e vivia do produto de seu trabalho. (AVÉ-LALLEMANT, 1859, p. 174-184)

O escritor Gerstäcker (1862), o biólogo Breitenbach (1885, 1887), o geógrafo e cartógrafo Lange (1885), o naturalista Canstatt $(1877,1899)$ e o geógrafo e engenheiro Beschoren (1899) também associam seus relatos aos seus conhecimentos sobre a natureza, marcadamente influenciados pelo evolucionismo darwinista, e descrevem suas experiências de viagens pelo interior do sul do Brasil, a partir da surpresa diante do inusitado que a paisagem apresen- 
ta. Não raro, constroem seus relatos, a partir de suas memórias pessoais autobiográficas, e estruturando argumentos fundamentados na contradição entre a natureza refeita na Europa, por influência e interferência humana, e a natureza em seu estado natural e selvagem, neste novo mundo. Aqui, as descrições das colônias de imigrantes alemães, ou das existências concretas dos colonos imigrantes, buscam estimular o desejo do novo, do não vivido, da construção possivel de uma nova vida em um novo mundo, aos seus leitores.

O militar Hörmeyer $(1863,1966)$, através de suas publicações, principalmente "Was Georg seinen deutschen Landsleuten über Brasilien zu erzählen Weiss - 0 que Jorge conta sobre o Brasil", também se vincula a este primeiro grupo. Contratado pelo governo imperial para compor as tropas de mercenários destinados à Guerra do Prata ou Guerra contra Oribe e Rosas (1851-1852), percorreu o vasto território do Rio Grande do Sul até 1954, quando deixou o exército. Seu livro tem um caráter autobiográfico e um estilo romanceado, intencionalmente convincente e, com certeza, tinha como objetivo a divulgação do Brasil como um destino "aprazivel" para os pobres emigrantes de língua alemã, na segunda metade do século XIX. Submetendo a crítica aos boatos sobre as cartas escritas por imigrantes instalados no Brasil, Hörmeyer (1966, p. 128) escreve:

Por vezes escrevíamos cartas, mas, creio que nos cinco anos na fazenda não escrevemos mais de três [...]. Sei que isso não é bom; pois há bastante gente que escreve à toa e todos clamam que os colonos levam uma vida desesperadamente má. As cartas dos que se deram bem não chegam e se algumas alcançam a Alemanha, diz-se, por causa de sua raridade, que são ditadas pelos patrões, são pura mentira. Mas o homem do campo não gosta de escrever: o árduo trabalho torna as mãos duras e impróprias para manejar a pena. Quanto mais laborioso é um camponês, tanto menos tempo e gosto tem ele de escrever; deixa de um domingo para o outro e se a mulher não o senta à mesa e não lhe põe na mão a pena, o tinteiro e o papel, não escreve. Esta é a razão porque encerram queixas muitas cartas. É que são escritas por sujeitos preguiçosos, que têm mais jeito para a pena do que para os trabalhos do campo e que não querem se conformar com a ocupação a que não estão habituados.

A partir da unificação alemã, em 1871, os relatos e diários de viagens, como, por exemplo, do empresário Fabri (1894); do economista político Jannasch $(1898,1905)$; do teólogo Funke (1902); e, do teólogo Lacmann (1906), todos aqui anunciados como exemplos, são explicitamente marcados pelos princípios nacionalistas do Deutschtum - Germanismo -, em grande medida ancorados na ideia de que a tardia unificação da Alemanha exigiria uma estratégia distinta da conquista e dominação imperialista de colônias, principalmente na África e Ásia, por potências europeias unificadas desde o século XVI ou XVII. Associando a sobrevivência, a permanência e a expansão da cultura dos imigrantes alemães, que haviam fundado e povoado colônias agrícolas no sul do Brasil, com a possibilidade de organizar uma força política com bases culturais nacionalistas em proveito dos interesses econômicos e políticos do Segundo Império - Zweite Reich:

Praticamente adaptando uma das teses da filosofia de Hegel, Fabri via na instrumentalização da emigração uma das funções naturais do Estado: 'Todo organismo estatal poderoso necessita [...] de um espaço territorial para lançar o excedente de suas forças produtivas e para captar a produção destas em um constante movimento dialético'. O não cumprimento desta função era visto por Fabri, não só como um desperdício de uma oportunidade histórica, mas também como uma forma de fortalecer o concorrente norte-americano, cuja economia se beneficiava da emigração espontânea de força de trabalho alemã para aquele país. (WIRT, 1998, p. 165)

Todas os autores e obras acima mencionados buscam estimular, a partir de narrativas de 
bases estruturalmente autobiográficas: - por um lado, a propagação da estratégia política do Estado Alemão em financiar as bases culturais dos emigrados para o sul do Brasil, como a imprensa em língua alemã, associações esportivas e culturais, mas principalmente escolas e igrejas luteranas; - por outro lado, através da divulgação de seus livros também entre os colonos imigrantes (a disposição nas bibliotecas das escolas e associações, ou reproduzidos nos jornais em língua alemã), como forma de recuperar e preservar a língua, os hábitos e os costumes alemães. Contudo, é importante reconhecer que a promoção e a circulação destes valores e ideologias étnicas nunca alcançaram seus propósitos políticos, pois os imigrantes e seus descendentes não deixaram de sofrer os efeitos de viver e significar suas existências em um novo espaço físico e cultural, fundindo o que eram, quando emigraram, ao que viviam e construíram no Brasil, como imigrantes.

No que diz respeito ao segundo grupo, os diários e cartas de imigrantes, como já afirmado acima, foram estrategicamente utilizados como forma de propagar interesses e estimular deslocamentos migratórios. Exemplo dessa afirmação é a divulgação de cartas de imigrantes, principalmente do Brasil, através de jornais, folhetins e livretos. Um dos mais importantes é:

Günther Fröbel (1811-1878) que herdou de seu pai em 1835 a Gráfica e Editora 'Löwesche' em Rudolstadt, que desde 1769 publicava o jornal 'Rudolstädter Wochenblatt', um dos mais importantes da região de Schwarzburg-Rudolstadt. Em 1845 Fröbel abriu uma agência de emigração na cidade, e em 1846/47 fundou o jornal 'Allgemeine Auswanderungs-Zeitung' ('Jornal Geral de Emigração' - 1846-1871) que em breve se tornaria, juntamente com a 'Deutsche Auswanderer-Zeitung' de Bremen ('Jornal Alemão de Emigração' - 1852-1875), o jornal especializado em emigração mais importante da Alemanha no decorrer do século XIX. Com a fundação da 'Allgemeine Auswandrungs-Zeitung', Fröbel pretendia preencher uma lacuna no mercado já que [...] não havia um periódico destinado a informar e orientar os emigrantes. [...] Segundo ele, havia à disposição dos emigrantes livros de viagem, guias e outras publicações especializadas no tema. Mas o grande problema, a seu ver, era que as informações contidas nessas publicações envelheciam rapidamente. 0 emigrante necessitava de informações e datas recentes fornecidas por um órgão imparcial e confiável. [...] 0 editor deixava claro que o jornal não pretendia incentivar a emigração, mas sim ajudar e orientar os seus compatriotas que já haviam tomado tal decisão. [...] Além da publicação da 'Allgemeine Auswanderungs-Zeitung', continuou a inserir pequenos informes, anúncios e cartas de emigrantes no suplemento do 'Rudolstdäter Wochenblatt' e, em meados de 1852, passou a publicar um folheto gratuito para ser distribuido juntamente com o jornal, o 'Fliegende Blätter für Auswanderer'('Folhetos para Emigrantes'). A partir de 1855, Fröbel ainda lançou no mercado 'Der Pilot - Unterhaltendes Wochenblatt zur Allgemeine Auswanderungs-Zeitung' ('O Piloto - Semanário de Entretenimento do Jornal Geral de Emigração'), um suplemento semanal do seu principal jornal. (ALVES, 2003, p. 156)

Havia um controle rígido sobre a divulgação de cartas dos imigrantes, tanto entre as autoridades brasileiras, especialmente os diretores das colônias; quanto entre agentes de emigração e diretores de jornais alemães, como Fröbel. Todos censurando ou deixando de encaminhar e divulgar as que fossem críticas negativas ao Brasil e a imigração (ALVES, 2003, p. 158-159); e estimulando, também, a divulgação, através da publicação das cartas com descrições positivas sobre o Brasil e suas condições de colonização através da imigração.

Peter Kleudgen, um agente da colonização com imigrantes alemães da Colônia de Santa Cruz, no Rio Grande do Sul, entre 1851 e 1854, fixou-se em Hamburgo, na Alemanha, e publicou duas brochuras $(1852,1853)$ para dar publicidade a suas atividades, nelas publicando várias cartas de imigrantes que enalteciam a imigração para o Brasil e para a Colônia de Santa Cruz. 
Os temas que são recorrentes nas cartas dizem respeito à viagem, ao clima, à condição de ser proprietário de terras, à alimentação, à fertilidade do solo e aos cultivos, à posse de animais de criação e ao fato de se tornarem homens livres. Estas cartas procuravam enaltecer as boas condições de vida dos colonos de Santa Cruz e ressaltar que ali a situação era melhor do que nos Estados Unidos ou do que em outras colônias do Brasil. Os textos não revelam problemas e inquietações pelos quais passavam os colonos assentados em Santa Cruz. Certamente, com o intuito de dar credibilidade às correspondências, as cartas apresentam o nome dos colonos, o nome dos destinatários e o seu local de moradia na Alemanha (CUNHA; VOGT; RADÜNZ, 2017).

\section{Finalizando}

Recuperando a memória e os usos das narrativas biográficas e autobiográficas, desde a antiguidade até o presente, na civilização ocidental, depreende-se que, enquanto humanos, vivemos a experiência sensivel da realidade, sempre a partir de perspectivas concretas, materiais, subjetivas, imaginativas e reflexivas. A abordagem desta temática, a partir de memórias de viajantes, diários e cartas de imigrantes, estimula a pesquisa e a reflexão na afirmação de que sempre nos construímos individual e coletivamente a partir de uma determinada perspectiva, criando, anunciando, ressaltando, omitindo ou negando certos aspectos, pois nossa história contada é influenciada, senão determinada, por nossos interesses particulares e seus encontros com a realidade existencial.

As concepções modernas, de modo especial das ciências sociais e humanas, enfatizam as realidades exteriores e localizam a interpretação da existência humana, individual ou coletiva, em bases objetivas: - "O 'lá fora' determina largamente o 'aqui dentro',
[...] Um sonho de imigrante: mude o mundo $e$ você muda a pessoa. No entanto, essas determinantes sociais permanecem condições externas, econômicas, culturais e sociais." (HILLMAN, 1993, p. 11).

E além disso:

[...] a realidade é de dois tipos: primeiro, o mundo significa a totalidade dos objetos materiais existentes ou a soma das condições do mundo exterior. A realidade é pública, objetiva, social e, normalmente, física; segundo, existe uma realidade psíquica não avaliada em espaço - o reino da experiência particular, que é interior, desejosa, imaginativa. [...] a divisão é realmente preocupante. Isso significa que a realidade psíquica não foi concebida para ser pública, objetiva ou física, enquanto a realidade exterior, a soma dos objetos e das condições materiais existentes, foi concebida para ser completamente destituída de alma. Assim como a alma existe sem mundo, o mundo também existe sem alma. [...] Essa visão não apenas mata as coisas por vê-las como mortas; ela nos aprisiona naquele pequeno e apertado cubículo do ego. (HILLMAN, 1993, p. 12-15)

A interpretação hermenêutica de relatos e narrativas de viagens, memórias, diários e cartas de imigrantes, fragiliza e derruba esta determinante. $\mathrm{E}$ o faz por possibilitar uma interpretação que, considerando e contextualizando a proveniência do narrado, recupera o vigor originário do pensamento. "O vigor do mistério e o vigor da verdade" (LEÃO, WRUBLEWSKI, 1993, p. 15). Pode levar (e leva!) à interpretação necessária de que a realidade objetiva, realmente existente, mas, igualmente transmitida por outros como visão exterior, através de diferentes estratégias sempre ancoradas na linguagem, precisa ser reelaborada. A modernidade conservadora ancorase na estratégia social de fazer cada sujeito, mesmo quando organizado coletivamente, a atribuir a si e conceber sua realização a partir da mesmidade da identificação - identidade: - "O indivíduo estrutura o seu eu por meio de 
trocas identificatórias com o que o rodeia, interiorizando modelos e imagens" (KAUFMAN, 2004, p. 24).

As práxis biográficas e autobiográficas, historicamente acessadas até o tempo presente, possuem tanta unidade entre si quanto um arquipélago ou uma constelação. Mas, mesmo diante desta disseminação de territórios, não deixam de ter unidade enquanto um conjunto de diversidades. Um corpus de sentidos, significados e estratégias, fundamentais para a ressignificação da pesquisa sobre o humano, em seus variados contextos. $E$ mais, creio que a recuperação da memória, disto que podemos chamar de genealogia do papel das narrativas biográficas e autobiográficas, pode nos levar a um campo investigativo precioso que nos permitirá construir as bases da crítica e da superação da identidade - estratégia tradicionalmente conservadora da modernidade atual - e alcançar uma nova instância, não apenas de compreensão e conceituação do humano, mas de sobrevivência: - a unidade!

\section{Referências}

ABELARDO, Pedro. A história das minhas calamidades. Tradução de Ângelo Ricci e Ruy Afonso da Costa Nunes. São Paulo: Abril Cultural, 1984.

ALVES, Débora Bendocchi. Cartas de imigrantes como fonte para o historiador: Rio de Janeiro/Turíngia (1852-1853). Revista Brasileira de História, São Paulo, v. 23, n. 45, p. 155-184, jul. 2003.

AVÉ-LALLEMANT, Robert. Reise durch Süd-Brasilien im Jahre 1858. Leipzig: Brockhaus, 1859.

BENJAMIN, Walter. Briefe. Gershom Scholem und Theodor Ludwig Wiesengrund-Adorno (Hrgs.). Frankfurt am Main: Suhrkamp, 1978.

BENJAMIN, Walter. Diário de Moscou. Tradução de Henrique Herbol. São Paulo: Cia. das Letras, 1989.

BENJAMIN, Walter. Das Passagen-Werk. Erster Band. Frankfurt am Main: Suhrkamp, 1993a.
BENJAMIN, Walter. Das Passagen-Werk. Zweiter Band. Frankfurt am Main: Suhrkamp, 1993b.

BENJAMIN, Walter. Gesammelte Briefe, 1910-1918. Band I. Christoph Gödde und Henri Lonitz. (Hrgs.). Frankfurt am Main: Suhrkamp, 1997a.

BENJAMIN, Walter. Gesammelte Briefe, 1919-1924. Band II. Christoph Gödde und Henri Lonitz. (Hrgs.). Frankfurt am Main: Suhrkamp, 1997b.

BENJAMIN, Walter. Gesammelte Briefe, 1925-1930. Band III. Christoph Gödde und Henri Lonitz. (Hrgs.). Frankfurt am Main: Suhrkamp, 1997c.

BENJAMIN, Walter. Gesammelte Briefe, 1931-1934. Band IV. Christoph Gödde und Henri Lonitz. (Hrgs.). Frankfurt am Main: Suhrkamp, 1997d.

BENJAMIN, Walter. Gesammelte Briefe, 1935-1937. Band V. Christoph Gödde und Henri Lonitz. (Hrgs.). Frankfurt am Main: Suhrkamp, 1997e.

BENJAMIN, Walter. Gesammelte Briefe, 1938-1940. Band Vl. Christoph Gödde und Henri Lonitz. (Hrgs.). Frankfurt am Main: Suhrkamp, $1997 f$.

BESCHOREN, Max. Beiträge zur nähern Kenntnis der brasilianischen Provinz São Pedro do Rio Grande do Sul. Reisen und Beobachtungen während der Jahre 1875-1887 von Max Beschoren. In: Ergänzungsheft n. 96 zu „Petermanns Mitteilungen“. Gotha: Justus Perthes, 1889.

BINGEN, Hildegard von. Scivias. Tradução de Columba Hart e Jane Bishop. New York: Paulist Press, 1990.

BINGEN, Hildegard von. Scivias - Wisse die Wege; eine Schau von Gott und Mensch in Schöpfung und Zeit. Freiburg: Herder, 1992. Tradução Walburga Storch.

BINGEN, Hildegard von. The Book of the Rewards of Live. New York: Oxford University Press, 1997. Tradução de Bruce Hozeski.

BINGEN, Hildegard von. Das Buch vom Wirken Gottes (Liber divinorum operum). Augsburg: Pattloch, 1998. Tradução de Mechthild Heieck.

BINGEN, Hildegard von. Book of Divine Works of Hildegard of Bingen. Charlotte: VT Medievals, 2009. Tradução de Priscilla Throop. 
BONI, Luiz Alberto de. De Abelardo a Lutero: estudos sobre filosofia prática na Idade Média. Porto Alegre: Edipucrs, 2003.

BRANDÃO, Junito de Souza. Mitologia grega. v. I. Petrópolis, RJ: Vozes, 2002.

BREITENBACH, Wilhelm. Die Provinz Rio Grande do Sul, Brasilien, und die deutsche Auswanderung dahin. Heidelberg: Winte, 1885.

BREITENBACH, Wilhelm. Über das Deutschtum in Süd-Brasilien. Hamburg: Richter, 1887.

BRUNN, Gerhard. Deutschland und Brasilien (18891914). Köln/Wien: Böhlau, 1971.

CANSTATT, Oskar. Brasilien. Land und Leute. Berlin: Ernst Siegfried Mitler und Sohn, 1877.

CANSTATT, Oskar. Die republikanische Brasilien in Vergangenheit und Gegenwart. Nach den neuesten amtlichen Quellen und auf Grund eigener Anschauung. Lepzig: Ferdinand Hirt und Sohn, 1899.

CASTRO, Luciana Xavier de. Religião em Rousseau: a profissão de fé do Vigário Saboiano. 2010. 148 f. Dissertação (Mestrado em Filosofia) - Programa de Pós-Graduação em Filosofia, Universidade Federal de Uberlândia, Uberlândia, 2010.

CUNHA, Jorge Luiz da. Os colonos alemães e a fumicultura. Santa Cruz do Sul: FISC, 1991.

CUNHA, Jorge Luiz da. Rio Grande do Sul und die deutsche Kolonisation. Ein Beitrag zur Geschichte der deutsch-brasilianischen Auswanderung und der deutschen Siedlung in Südbrasilien zwischen 1824 und 1914. Santa Cruz do Sul, RS: Gráfica Léo Quatke da UNISC, 1995.

CUNHA, Jorge Luiz da. Da miséria fugiram! (Pelo menos a maioria). In: FISCHER, Luís Augusto; GERTZ, René Ernaini. Nós, os teuto-gaúchos. Porto Alegre: Editora da UFRGS, 1996. p. 255-266.

CUNHA, Jorge Luiz da. Os que deixam a terra natal. ZERO HORA, Porto Alegre, 24 jul. 2004. Segundo Caderno, p. 2-3.

CUNHA, Jorge Luiz da; VOGT, Olgário Paulo; RADÜNZ, Roberto. Peter Kleudgen: um negociador alemão agenciando colonos para o Brasil. In: FRASQUET, Ivana; ESCRIG, Josep; RENAU, Laura Martínez. (Eds.). XVII CONGRESO AHILA. En los márgenes de la Historia Tradicional. Nuevas miradas de America Latina desde el siglo XXI. Valencia: Universitat de Valencia. 09 de septiembre de 2017. p. 1708-1727.

DELORY-MOMBERGER, Christine. A condição biográfica. Ensaios sobre a narrativa de si na modernidade avançada Tradução de Carlos Galvão Braga, Maria da Conceição Passeggi e Nelson Patriota. Natal: Edufrn, 2012.

FABRI, Carl. Europäische Einwanderung nach Brasilien. Colonialpolitische Betrachtungen zur augenblicklichen Lage Brasiliens. Hamburg: Lütcke \& Wulff, 1894.

FISCHER, Joseph. Die Erkenntnislehre Anselms von Canterbury nach den Quellen dargestellt (Beiträge zur Geschichte der Philosophie des Mittelalters. Bd. 10, Heft 3). Münster: Westfälische Wilhelms-Universität, 1911.

FUNKE, Alfred. Aus Deutsch-Brasilien. Bilder aus dem Leben der Deutschen im Staate Rio Grande do Sul. Lepzig: Teubner, 1902.

GERSTÄCKER, Friedrich. Achtzehn Monate in Südamerika und dessen deutschen Kolonien. Jena: Costenoble, 1862.

GILSON, Étienne. A filosofia na Idade Média. São Paulo: Martins Fontes, 2007.

GOETHE, Johann Wolfgang von. Fausto: uma tragédia - Primeira parte. Tradução de Jenny Klabin Segall. São Paulo: Editora 34, 2007a.

GOETHE, Johann Wolfgang von. Fausto: uma tragédia - Segunda parte. Tradução de Jenny Klabin Segall. São Paulo: Editora 34, $2007 b$.

GOETSCH, Paul. Das Reichsgesetz über das Auswanderungswesen vom 9.VII.1897 nebst Ausführungsverordnungen, unter Benutzung amtlicher Quellen erläutert. Taschen-Gesetzsammlung nr. 37. Berlin: Carl Hermann Verlag, 1898.

HEIDEGGER, Marin. Ser e o tempo. Tradução de Marcia Sá Cavalcante Schuback. Parte I. Petrópolis, RJ: Vozes, 2002a. 
HEIDEGGER, Marin. Ser e o tempo. Tradução de Marcia Sá Cavalcante Schuback. Parte II. Petrópolis, RJ: Vozes, 2002b.

HESÍODO. Teogonia. A origem dos deuses. Tradução de Jaa Torrano. São Paulo: Iluminuras, 1995.

HILLMAN, James. Cidade \& alma. Tradução de Gustavo Barcellos e Lúcia Rosenberg. São Paulo: Studio Nobel, 1993.

HOLLISTER, Charles Warren. Medieval Europe. A short history. New York: John Wiley \& Sons, 1982.

HÖRMEYER, Joseph. Was Georg seinen deutschen Landsleuten über Brasilien zu erzählen weiss. Schilderungen eines in Süd-Brasilien wohlhabend gewordenen Proletariers. Ein Beitrag zur Länderund Völkerkunde. Leipzig: Rein, 1863.

HÖRMEYER, Joseph. 0 que Jorge conta sobre o Brasil. Tradução de Bertholdo Klinger. Rio de Janeiro: Presença, 1966.

JANNASCH, Robert. Ratschläge für Auswandern nach Süd-Brasilien. Berlim: Allgemeine Verlags-Agentur, 1898.

JANNASCH, Robert. Land und Leute von Rio Grande do Sul. Berlim: Export, 1905.

JULIEN, Nadia. Dicionário Rideel de Mitologia. Tradução de Denise Radonovic Vieira. São Paulo: Rideel, 2005.

KERÉNYI, Karl. A mitologia dos gregos. V. I. A história dos deuses e dos homens. Tradução de Octavio Mendes Cajado. Petrópolis, RJ: Vozes, 2015.

KAUFMAN, Jean-Claude. A invenção de si. Uma teoria da identidade. Tradução de Joana Chaves. Lisboa: Instituto Piaget, 2004.

KLEUDGEN, Peter. Die deutsche Kolonie Santa Cruz, Provinz Rio Grande do Sul, Süd-Brasilien, von Peter Kleudgen, bevollmächtigtem Agenten gennanter Provinz. Hamburg: Druck von J. J. Nobilig, 1852.

KLEUDGEN, Peter. Die deutsche Kolonie Santa Cruz in der Provinz Rio Grande do Sul, Süd-Brasilien, nach den neusten Nachrichten dargestellt von Peter Kleudgen, Regierungsbevollmächtigtem der gennanten Provinz. Hamburg: Verlagsbuchhandlung von Robert Kittler, 1853.

LACMANN, Wilhelm. Ritte und rasttage in Südbrasilien: reisebilder und studien aus dem leben der deutschen siedelungen. Berlin: Dietrich Reimer, 1906.

LANGE, Henry. Südbrasilien. Die Provinz Sao Pedro do Rio Grande do Sul, Santa Catarina und Parana mit Rücksicht auf die Deutsche Kolonisation. Leipzig: Verlag von Paul Phohberg, 1885.

LEÃO, Emmanuel Carneiro; WRUBLEWSKI, Sérgio. (Orgs.). Os pensadores originários: Anaximandro, Parmênidas, Heráclito. Petrópolis, RJ: Vozes, 1993.

LEBRUN, Gérard. A filosofia e sua história. Tradução de Carlos Alberto Ribeiro de Moura. São Paulo: Cosac Naify, 2006.

LEIGH, Ralph Alexander. (Org.). Correspondance complete de Rousseau. Oxford: Oxford University Press, 1972.

MARQUES, José Oscar de Almeida. (Org.). Cartas a Christophe de Beaumont; cartas a Malesherbes; carta de J.-J. Rousseau ao senhor de Voltaire; cartas morais; carta ao senhor de Franquières; fragmentos sobre Deus e sobre a revelação. Tradução de Adalberto Luis Vicente, Ana Luiza Silva Carani, José Oscar de Almeida Marques e Maria Cecília Queiroz de Moraes Pinto. São Paulo: Estação Liberdade, 2005.

NEWMAN, Barbara. Hildegard and her Biographers: the remaking of female sainthood. In: MOONEY, Catherine $M$. Gendered voices: medieval saints and their interpreters. The Middle Ages series. Philadelphia: University of Pennsylvania Press, 1999. p. 1634.

PADOVANI, Humberto; CASTAGNOLA, Luís. História da filosofia. São Paulo: Melhoramentos, 1962.

RICCI, Angelo. Nota introdutória. In: SANTO AGOSTINHO. De magistro. Porto Alegre: Universidade do Rio Grande do Sul, 1956. p. 7-10.

RICOEUR, Paul. 0 si-mesmo como um outro. Tradução de Lucy Moreira Cesar. Campinas, SP: Papirus, 1991. 
ROUSSEAU, Jean-Jacques. As confissões. Tradução de Wilson Louzada. Rio de Janeiro: Tecnoprint, 1965.

ROUSSEAU, Jean-Jacques. Emilio ou da educação. Tradução de Roberto Leal Ferreira. São Paulo: Martins Fontes, 2004.

ROUSSEAU, Jean-Jacques. Confissões. Tradução de José Benedicto Pinto e Rachel de Queiroz. São Paulo: Edipro, 2008a.

ROUSSEAU, Jean-Jacques. Os devaneios do caminhante solitário. Les Rêveries du promeneur solitaire. Tradução de Julia da Rosa Simões. Porto Alegre: L\&PM, 2008b.

SANTO AGOSTINHO. Confissões. Tradução de Maria Luiza Jardim Amaranto. São Paulo: Paulus, 1984.

SANTO AGOSTINHO. Confissões. Tradução de Lorenzo Mammi. São Paulo: Penguin Classics; Cia. das Letras, 2017.

SANTO AGOSTINHO. A cidade de Deus. Petrópolis, RJ: Vozes, 2002.

SCHIPPERGES, Heinrich. Hildegard von Bingen. Prin- ceton: Markus Wiener Publishers, 1997.

SELIGMAN-SILVA, Márcio. O esplendor das coisas: o diário como memória do presente na Moscou de Walter Benjamin. Revista Escritos, Rio de Janeiro, Fundação Casa de Rui Barbosa, v. 3, n. 3, p. 161-185, 2009.

SOËTARD, Michel. Jean-Jacques Rousseau. Tradução de Verone Lane Rodrigues. Recife: Fundação Joaquim Nabuco; Editora Massangana, 2010.

VEYNE, Paul. Acreditavam os gregos em seus mitos? Tradução de Horácio González e Milton Meira Nascimento. São Paulo: Brasiliense, 1984.

WIRT, Lauri Emilio. Protestantismo e etnia: sobre a preservação da identidade étnica no protestantismo de imigração. Estudos Teológicos, São Leopoldo, Programa de Pós-Graduação em Teologia da Escola Superior de Teologia, v. 23, n. 2, p. 156-172, mai./ago. 1998.

Jorge Luiz da Cunha é Doutor em história medieval e moderna/contemporânea pela Universität Hamburg, Alemanha. Professor Titular da Universidade Federal de Santa Maria. Coordenador do Núcleo de Estudos sobre Memória e Educação - CLIO. Presidente da Associação Brasileira de Pesquisa (Auto)biográfica). e-mail: jlcunha11@yahoo.com.br

Universidade Federal de Santa Maria - UFSM, Centro de Educação, Prédio 16, Sala 3178. Cidade Universitária - Camobi. CEP 97.105-900 - Santa Maria - RS. Telefone: +55-55-99152-4713 